\title{
Amplification or suppression: \\ Social networks and the climate change - migration association in rural Mexico
}

Raphael J. Nawrotzki ${ }^{\mathrm{a}}$, Fernando Riosmena ${ }^{\mathrm{b}}$, Lori M. Hunter ${ }^{\mathrm{c}}$, and Daniel M. Runfola ${ }^{\mathrm{d}}$

${ }^{\text {a }}$ Corresponding Author; University of Minnesota, Minnesota Population Center, 225 19th Avenue South, 50 Willey Hall, Minneapolis, MN 55455, U.S.A.

Phone: +001 (612) 741-0070

e-mail: r.nawrotzki@gmail.com

${ }^{\mathrm{b}}$ University of Colorado Boulder, Institute of Behavioral Science, CU Population Center, 1440 15th Street, Boulder, CO 80302, U.S.A.

e-mail: Fernando.Riosmena@ colorado.edu

${ }^{\mathrm{c}}$ University of Colorado Boulder, Institute of Behavioral Science, CU Population Center, 1440 15th Street, Boulder, CO 80302, U.S.A.

e-mail: Lori.Hunter@colorado.edu

${ }^{\mathrm{b}}$ The College of William and Mary; 427 Scotland Street, Williamsburg, VA 23185, U.S.A. e-mail: drunfola@aiddata.org

Acknowledgements:

This article is based on Chapter VI of Raphael Nawrotzki's dissertation titled "Climate Change as a Migration Driver in Mexico, 1986-99". The authors gratefully acknowledge support from the Minnesota Population Center (5R24HD041023) and the University of Colorado Population Center (R24 HD066613), funded through grants from the Eunice Kennedy Shriver National Institute for Child Health and Human Development (NICHD). We thank Richard G. Rogers and Fred C. Pampel for insightful comments on the substantive contributions of this research and helpful advice on the statistical model development. We also express our thanks to Gina Rumore for her careful editing and suggestions. And last but not least, special thanks to two anonymous reviewers and the journal editors for helpful comments and suggestions on earlier drafts of this manuscript.

Social networks and the climate change - migration association in rural Mexico 


\begin{abstract}
Increasing rates of climate migration may be of economic and national concern to sending and destination countries. It has been argued that social networks - the ties connecting an origin and destination - may operate as "migration corridors" with the potential to strongly facilitate climate change-related migration. This study investigates whether social networks at the household and community levels amplify or suppress the impact of climate change on international migration from rural Mexico. A novel set of 15 climate change indices was generated based on daily temperature and precipitation data for 214 weather stations across Mexico. Employing geostatistical interpolation techniques, the climate change values were linked to 68 rural municipalities for which sociodemographic data and detailed migration histories were available from the Mexican Migration Project. Multi-level discrete-time eventhistory models were used to investigate the effect of climate change on international migration between 1986 and 1999. At the household level, the effect of social networks was approximated by comparing the first to the last move, assuming that through the first move a household establishes internal social capital. At the community level, the impact of social capital was explored through interactions with a measure of the proportion of adults with migration experience. The results show that rather than amplifying, social capital may suppress the
\end{abstract}


sensitivity of migration to climate triggers, suggesting that social networks could facilitate climate change adaptation in place.

Key words: International migration; climate change; rural Mexico; social networks; suppression mechanism; amplification mechanism

Amplification or suppression:

Social networks and the climate change - migration association in rural Mexico

\section{Introduction}

Climate change is of global concern but has differential local impacts due to variation in exposure, sensitivity, and adaptive capacity across settings (Adger et al., 2005). The latest projections of the Intergovernmental Panel on Climate Change (IPCC) suggest that profound changes in the climatic system during the $21^{\text {st }}$ century will likely be felt hardest by households in developing countries that strongly depend on agricultural production (IPCC, 2013, 2014). Households in lower-income contexts more likely lack the means to protect against adverse climate events using technological buffers (Gutmann and Field, 2010; Huq et al., 2003).

Rural Mexican households are particularly vulnerable to climate change. Although not entirely dependent on agricultural production, this livelihood activity contributes up to two-thirds of rural Mexican household income (de Janvry and Sadoulet, 2001). Because of its small, often non-commercial scale, much of Mexico's rural agricultural sector lacks even the most basic technological buffers to climate change. For example, in 2001 only about one quarter of permanently cropped land was irrigated (Carr et al., 2009). Due to the lack of technological buffers, climate and weather events have led to major economic losses within the agricultural 
sector (Saldana-Zorrilla and Sanberg, 2009). Adding to this, the liberalization of the Mexican economy has increased household sensitivity to changes in climate and market conditions (Eakin, 2005).

Under conditions of climate change-related livelihood insecurity, households engage in various forms of livelihood diversification. Families may reduce nonessential expenditures, adopt new livelihood activities, use formal and informal credit, or draw on public assistance (Gray and Mueller, 2012). Alternatively or in conjunction, families may send a member elsewhere to access alternative income sources, resulting in remittances to the origin household (McLeman and Smit, 2006). While temporary labor migration in the context of climatic vulnerability is often directed toward nearby urban areas, households may also send members abroad. The New Economics of Labor Migration (NELM) theory (Stark and Bloom, 1985) suggests that, in the absence of functioning insurance (e.g., crop insurance) and capital markets (e.g., to obtain credit to buy equipment or install irrigations systems), international destinations may be preferred as their economic and climatic conditions are often less correlated with those in the sending area (Massey et al., 1993).

Despite this advantage, international migration is a costly venture and across much of the Global South climate shocks are generally not associated with international but rather with shorter-distance, internal movement (e.g., Henry et al., 2004; Massey et al., 2010). Rural Mexico, however, constitutes an exception to this pattern given the long history of cross-border labor flows to the United States. Consistent with the NELM theory, a number of studies find a direct relationship between precipitation decline and Mexico-U.S. migration (Feng and Oppenheimer, 2012; Hunter et al., 2013; Munshi, 2003; Nawrotzki et al., 2013). On the whole, however, this work finds a highly situated climate-migration relationship, in which associations 
are only found in particular regional contexts depending on factors such as historical climatic conditions (Nawrotzki et al., 2013), the history of migration (Hunter et al., 2013), and urbanization levels (Feng and Oppenheimer, 2012).

Recently, a number of authors have stressed the importance of social networks connecting origins and destinations for the climate-migration association (Adamo and de Sherbinin, 2011; Bardsley and Hugo, 2010). Such networks may operate as "migration corridors" with the potential to amplify climate-related international migration (Bardsley and Hugo, 2010, p. 249) since, it is argued, even small environmental triggers may spur large-scale migration. However, migrant networks may also come with information and resources that increase in situ adaptive capacity and thus could reduce or suppress the climate-migration association. Understanding whether migration-receiving hubs will face increasing or decreasing rates of immigration due to climate change may be of economic and national concern to sending and destination countries.

Social networks are a key facilitator of U.S.-bound migration from rural Mexico and provide aspiring migrants with knowledge about the migration process as well as connections to the destination's labor markets (Massey and Aysa-Lastra, 2011; Davis et al., 2002; Fussell, 2004; Massey and Riosmena, 2010). Because many communities across rural Mexico have wellestablished migration corridors (Durand and Massey, 2003; Massey et al., 2002; Hamilton and Villarreal 2011), Mexico presents a suitable case to study the potential of social networks influence on the climate-migration association.

In this paper, we explore the moderating effect of social networks on the climatemigration relationship using climate data with a more refined spatial resolution than much prior work on Mexico-U.S. migration (e.g., Hunter et al., 2013; Nawrotzki et al., 2013). In addition to 
rainfall effects, we also examine the influence of temperature, a factor largely ignored in the Mexican climate-migration literature despite its significant impact on crop yields (Lobell and Field, 2007) and resulting agricultural income (Mueller et al., 2014). We employ a set of 15 climate change indices proposed by the Expert Team of Climate Change Detection and Indices (ETCCDI) to capture the impact of nuanced differences in temperature and precipitation extremes (Alexander et al., 2006). Making use of these climate change indices, we examine the role of social networks on migration to the U.S. from rural Mexico in response to climate change.

\section{Data and Methods}

\subsection{Data}

We combined detailed migration histories and sociodemographic data from the Mexican Migration Project (MMP) with daily temperature and precipitation data obtained from the Global Historical Climate Network-Daily (GHCN-D) (version number: 2.93-upd-2012082407), compiled and made publically available by the National Oceanic and Atmospheric Administration (NOAA). The MMP has collected data across different Mexican locales since 1982 (Massey, 1987a). Each year, 4-6 communities are purposefully selected throughout Mexico and a simple random sample of about 200 households per community is interviewed (once and only once). The MMP provides detailed retrospective information on the first and last U.S. migration of all de jure and de facto household members (i.e., including head and spouse, even if they are in the United States, as long as they are still considered members of the household), plus all children of the head regardless of place of residence at the time of the survey. While the detailed information comes at the cost of representativeness, studies have demonstrated that the 
MMP accurately reflects the characteristics and migration behavior of international migrants in Mexico (Massey and Capoferro, 2004; Massey and Zenteno, 2000). Moreover, the MMP samples are representative of the (rural) communities surveyed and, as such, represent a unique dataset to understand migration community processes (Riosmena, 2009). Due to these features, the MMP data have been used for a large number of migration research projects (e.g., Fussell and Massey, 2004; Hunter et al., 2013; Massey and Espinosa, 1997; Massey et al., 2015; Riosmena, 2009).

To construct the climate change indices we chose the GHCN-D data set because it provides the necessary daily readings of temperature and precipitation for an extended time period (for this project, 1961 to 1998). The GHCN-D data undergoes rigorous quality checks (Menne et al., 2012) and has been used in prior published work exploring changes in the climatic system (e.g., Alexander et al., 2006; Caesar et al., 2006).

\subsection{Unit of Analysis}

We conduct the analysis at the household level given that, in the Mexican context and consistent with the NELM theory, migration is a livelihood decision reached at the household level, rather than by a single individual (Cohen, 2004; Massey et al, 1993). Climate change indices were constructed at the municipality level $(n=68)$ and linked to rural MMP communities for which household-level migration data were available. We defined rural communities as those located in towns $(2,500-10,000$ inhabitants $)$ or ranchos $(<2,500$ inhabitants $)$. Figure 1 shows the location of the rural MMP municipalities as well as the weather stations for which daily temperature and precipitation data were available. 
(Figure 1 about here)

The impact of climate change on migration was investigated for the period 1986-99. Data limitations precluded analysis of more recent years. The number of weather stations available through GHCN-D, drops from an average of $n=182$ during 1961-98 to $n=15$ for more recent years, due to the historical focus of this data source. We did not include migration events before 1986 given the large impacts of the Immigration Reform and Control Act (IRCA) on MexicoU.S. migration dynamics (LoBreglio, 2004).

\subsection{Variable Construction}

\subsubsection{Outcome Variables}

The MMP defines migration as a move that involves a change in usual residence, excluding short visits for vacation, shopping, visits, and commuting (Fussell, 2004). For this study we were interested in two types of moves - the first and last move from within a household. We distinguish between them given the well-established notion that the "determinants" of migration vary considerably for those with and without prior migration experience (e.g., Massey and Espinosa, 1997). After the first move, a household has established more direct connections to the destination and these networks, as well as the first-hand knowledge about the migration process itself, may impact the strength with which external factors, such as climate change, influence the timing of a move.

The outcome variable was thus coded 0 for non-migrant households and 1 if a household had sent an international migrant to the U.S. For the first move, we obtained all years in which a household reported a first international move of any household member and selected the initial 
year a migrant was sent to the U.S. We also obtained the years in which household members engaged in the last move to the U.S. (after the first move had been completed) and selected the latest year within the household. The migration information was then used to construct a household-period data file that contains an entry for each year during the study period (1986-99) in which the household was at risk for migration. Households at risk for a first move are those that have not sent any member to the U.S. prior to the observation window. Households at risk for a consecutive move are those that have not sent a member to the U.S. for the second, third, etc. time but may have experienced a first move prior to the observation window. Households enter the dataset in 1986 when the household was formed (approximated by the current union formation) and the household head was at least 15 years old. Households leave the dataset when a household member migrates to the U.S. after 1986, the head turns 65 years old, the household is censored at data collection, or when the final year of the study period is reached in 1999. In addition household members may engage in domestic moves in and out of the study communities. We only expose households to the risk of migration during years when at least one core household member (household head or spouse) were present in the community. Our sample does not include members of entire households that emigrated abroad prior to the survey year. While this omission could bias our estimates, the amount of error is likely to be small in rural areas, where international migrants are more likely to return (Cornelius 1992; Riosmena 2004). The hazard of migration is shown in Figure 2.

(Figure 2 about here) 
Migration is often responsive to changes in border policies as well as economic conditions. The elevated levels of migration during 1988-90 and 1994-96 may reflect the impact of two major economic crises during these periods (Lustig, 1990; McKenzie, 2006). In addition, the SAW (Special Agriculture Worker) and RAW (Replenishment Agricultural Workers) sub-components of IRCA led to increased migration in the late 80s (Martin, 1990).

\subsubsection{Primary Predictor Variables}

The Expert Team on Climate Change Detection and Indices (ETCCDI), sponsored by the World Meteorological Organization and the United Nations, led an international effort to formulate a suite of 27 core indices with the goal to standardize the use of climate change measures to allow global comparisons across countries and study periods (Peterson and Manton, 2008). The ETCCDI climate change indices were developed for the Intergovernmental Panel on Climate Change (IPCC)'s Third Assessment Report (Peterson et al., 2001) and have been widely used for climatological research (e.g., Alexander et al., 2006; Bindoff et al., 2013) but have not been employed to explore the climate change-migration association. Most likely this omission is the result of a lack of interaction between the climate and demographic research communities (e.g., Hunter and O’Neill, 2014) as well as difficulties in constructing those measures, which requires some understanding of spatial statistics. The climate change indices can be broadly grouped into high temperature, low temperature, high precipitation, and low precipitation indices. Some of the indices are highly correlated and only differ in threshold levels. Since it was the goal of this research to assess the impact of substantively different types of climate change, we selected climate change indices so that the correlation within a subgroup remained below $r=0.70$, resulting in a set of 15 climate change indices (Table 1 ). 
(Table 1 about here)

Constructing the climate change indices was a four-step approach involving missing data imputation, index computation, spatial interpolation, and computation of relative change measures. Within the GHCN-D data set, about $20 \%$ of the daily recorders were missing, either because the readings failed the quality checks (c.f., Menne et al., 2012) or were not recorded (e.g., instrument errors). To impute the missing records, we used Multiple Imputation (MI) (Allison, 2002; Rubin, 1987), a state-of-the-art imputation method that accounts for the uncertainty in the imputation process by explicitly adding random variation to the estimates over several replications of the process (Little and Rubin, 2002; Honaker and King, 2010). We implemented this procedure using the R package Amelia (Honaker et al., 2011), which allows for the imputation of time-series data. In this case, we included a second order polynomial for time in the imputation model to account for seasonal changes in climatic conditions.

The imputed data set served as input for the computation of climate change indices, using the R package climdex.pcic managed and released by the Pacific Climate Impacts Consortium (Bronaugh, 2014). The climate change indices are based on daily temperature and precipitation data but are constructed as annual aggregates for each weather station. Because weather stations do not necessarily fall in the municipalities for which the migration data is available, we employed cokriging, implemented in a geographical information system (ArcGIS), as a method of spatial interpolation to estimate climate change index values at unknown locations. Cokriging, based on regionalized variable theory (Matheron, 1971), uses the spatial trend and the local spatial autocorrelation to inform the predictions (Hevesi et al., 1992; Bolstad, 2012). Cokriging allows for the inclusion of covariates, and we included information from a digital elevation 
model (DEM) in the cokriging model because of the correlation between altitude, temperature and precipitation. The DEM is based on remotely sensed images from the Shuttle Radar Topography Mission (SRTM, 30 arc-seconds resolution) created and released by the U.S. Geological Survey (USGS) and the National Geospatial-Intelligence Agency (NGA) (Danielson and Gesch, 2011). Due to its desirable properties, cokriging is frequently used to interpolate climate variables and indices (e.g., Aznar et al., 2013; Garzon-Machado et al., 2014). We compared our cokriging results with a gridded layer of the ETCCDI climate change indices of coarse resolution available through the HadEX2 data set (Donat et al., 2013). In addition, we performed a bootstrap procedure to compute error values for a subset of $10 \%$ of the weather stations that were randomly omitted from the interpolation. These tests confirmed that the interpolation produce reliable results. Following the cokriging procedure, climate change values were extracted from the interpolated surface using a $700 \times 700 \mathrm{~m}$ lattice of points, and the mean value was assigned to the respective MMP municipalities.

In a final step, we computed relative change measures by computing the difference between the climate change index value for a three-year window, leading up to each of the years in the study period and a 30-year reference period (1961-90). To make the climate change indices comparable, we divided the difference scores by the standard deviation measured for each municipality during the reference period. We chose a three-year window to reduce the influence of short-term climatic fluctuations and to capture lagged climate responses in line with prior research (Henry et al., 2004; Hunter et al., 2013). Table 2 displays summary statistics for the climate change indices.

(Table 2 about here) 
The trajectories of the temperature measures are largely in line with warming trends projected by the IPCC (2013). For example, the warm spell duration index during 1985 shows a mean value that is 0.21 standard deviation units below the 30 -year reference period; this duration increased over the years with a mean value that was 2.09 standard deviation units above the long term average in 1992 and reached a peak value of 6.32 in 1998. However, similar to other studies of historical climate patterns (Klein Tank et al., 2006), no clear trend could be discerned for precipitation measures.

\subsubsection{Control Variables}

Since we conceptualize migration as a livelihood strategy, we classify control variables according to livelihood capitals (financial, physical, social, human, and natural) as suggested by the sustainable livelihood framework (Carney et al., 1999; Scoones, 1999). The control variables capture various sociodemographic characteristics at the household and municipality level that may influence the decision to migrate. Variables were included as both time varying and time constant in the models and were derived from various sources (Table 3).

(Table 3 about here)

To capture differences in access to social capital we included a dummy variable indicating whether the household head was female (1=yes) as well as the marital status of the household head ( $1=$ married). In order to account for the influence of human capital, we included a measure of the number of young children (age $<5$ years) present within a household during each period, as well as measures of the household head's education level (number of years of schooling), 
work experience (cumulative number of years employed), and the occupational status (blue collar, white collar, unemployed/not in labor force). Household-level physical capital was measured by property and business ownership (1=owner). At the community level, social capital was measured as the percentage of adults with U.S. migration experience, known in the migration literature as the migration prevalence ratio (Fussell, 2004). To capture municipalitylevel wealth and the overall development stage, we constructed a standardized wealth index (Cronbach's alpha: 0.85 ) that combines 11 variables measuring the housing quality as well as service and infrastructure access. The migrant prevalence measure and the wealth index were available in decadal time steps and we used linear interpolation to obtain time-varying predictors as a common approach in event-history analysis (Allison, 1984). A measure of the percentage of the land area planted allows gauging agricultural dependence while the percentage of farmland irrigated captures the vulnerability of the local agricultural sector to climatic variations.

Measures for the average daily precipitation as well as the average daily temperature during the 30-year baseline period (1961-90) were included in all models to account for different climatic regimes. Finally, a municipality measure of the percentage of the male labor force employed in agriculture helps to assess the impact of employment in climate sensitive sectors.

\subsection{Estimation Strategy}

We employ discrete-time event history models (Allison, 1984; Singer and Willett, 2003; Steele, 2005), which have been frequently used to assess the impact of environmental factors on migration (e.g., Gray and Bilsborrow, 2013; Henry et al., 2004; Hunter et al., 2013; Mueller et al., 2014). However, due to the hierarchical data structure, we employ a multi-level version of the discrete-time event history models (Barber et al., 2000; Steele et al., 1996, 2004). To reduce 
the possibility of endogeneity, all predictors were lagged by one year (c.f., Gray, 2009, 2010). The employed model can be formally described as follows (Equation 1).

$$
\operatorname{logit}\left(h_{i j k}\right)=\alpha+\beta_{1}\left(c i_{i k}\right)+\sum_{n=2}^{y} \beta_{n}\left(x_{n z}\right)+u_{k}
$$

Equation 1, allows estimating the hazard that a household $j$ located in municipality $k$ experienced a migration event in period $i$ (separate models are estimated for first and last moves). The parameter $\alpha$ reflects the baseline hazard and was included as a set of dummy variables to allow for the most flexible representation of time (Singer and Willett, 2003). Although we are unable to fully capture non-linear effects of recall bias, all models control for the survey year in an attempt to account for an increase in uncertainty with longer temporal distance between the move and the survey year. The expression $\sum_{n=2}^{y} \beta_{n}\left(x_{n z}\right)$ represents the set of control variables operating at the household and municipality level. The coefficient $\beta_{1}$ reflects the effect of a generic timevarying climate change index $\left(c i_{i k}\right)$. It has been shown that time-varying context-level variables, such as the climate change indices, can be effectively modeled using a 2-level structure (Barber et al., 2000). Finally, the parameter $u_{k}$ constitutes the random effects term, capturing acrossmunicipality variation. The models were estimated within the $\mathrm{R}$ statistical environment version 3.1 (R Core Team, 2014), using the multilevel package lme4 (Bates, 2010; Bates et al., 2014). For increased speed and improved convergence properties, we adjusted the model settings (integer scalar setting of $\mathrm{nAGQ}=0$ ) so that the random-effects and the fixed-effects coefficients were optimized (optimizer = "bobyqa") in the penalized iteratively reweighted least squares step (Bates et al., 2014). 


\section{Theory: Social Networks' Impact on the Climate Change-Migration Association}

Our analytical focus is on the influence of social networks operating at household and community levels. To proxy for migrant networks at the household level, we distinguished between first and last moves, with the last move representing the second, third or further migration (e.g., Fussell, 2004). Through the first move, households establish internal social ties between origin and destination areas (Massey et al., 1987; Massey, 1990). Social capital, built through the first move, substantially increases the likelihood of a consecutive move (Curran and Rivero-Fuentes, 2003; Massey and Espinosa, 1997; Massey and Garcia Espana, 1987). Similarly at the community level, more local adults with migration experience increase international outmigration from rural areas (e.g., Fussel, 2004; Nawrotzki et al., 2013). Broadly two possible mechanisms suggest different underlying causal pathways linking social networks with migration and climate. We coin these "amplification" and "suppression" mechanisms.

Amplification mechanism. The amplification mechanism underlies much of the research on social networks' effects on environmental drivers. For example, the concept of "migration corridors" (Bardsley and Hugo, 2010, p. 249) proposes that, once established, a corridor reduces migration's cost and even relatively small environmental strains may yield large-scale migrations (see also, Adamo and de Sherbinin, 2011). Indeed, for the Mexican case, there is some evidence that community-based social capital may facilitate environmentally motivated moves (Hunter et al., 2013). If the amplification mechanism holds true, we would expect the effect of climate change on migration to be strongest for households with greater network access. In regression models, this would manifest in a significant interaction coefficient (climate change $x$ migration networks) that would have the same direction as the main effect of the climate change measure. Figure 3 provides a visual depiction of the amplification and suppression mechanisms. 
(Figure 3 about here)

Suppression mechanism: In this study, we propose the suppression mechanism as an alternative explanatory framework. It has been argued that the social capital contained in networks is crucial for climate change adaptation strategies other than migration (Adger, 2003; Pelling and High, 2005). Social networks not only provide relevant information about destination labor markets but also transmit information about risk management in the farming sector and other natural resource-based enterprises (c.f., Pretty and Ward, 2001). Moreover, transnational networks channel financial resources (e.g., remittances) that can be used for climate change adaptation at home. Prior research shows that in times of environmental strain remittance flows increase along established migrant networks (Gubert, 2002; Yang and Choi, 2007). Since social networks can facilitate origin-based climate adaptation through knowledge transfer and remittances, they may suppress the climate-migration association. In this case, we would anticipate climate effects on migration to be strongest when social networks are actually absent. This suppression mechanism is implicitly assumed by Henry et al. (2004), who argue that the first move represents a livelihood strategy more directly linked to the external environment as compared to subsequent migrations that are more heavily influenced by social networks. Also in support of the suppression mechanism, de Janvry et al. (1997) observed that migration from Mexican households without access to social networks was more strongly impacted by community and environmental characteristics compared to households that could draw on household-specific migrant networks. Within a regression model the suppression mechanism would manifest as a significant interaction coefficient (climate change $x$ migration networks) but with a sign opposite to the main effect of climate change. 


\section{Results and Discussion}

Migration is influenced by multiple sociodemographic and economic factors. To guard against reporting spurious relationships when investigating the climate change-migration association, it is important to establish a reliable base model of international (U.S.) migration from rural Mexico. Table 4 shows the fully adjusted multi-level discrete-time event history models for the first and last move from within a household.

(Table 4 about here)

Table 4 illustrates that households headed by females (Lindstrom and Lauster, 2001) and households with young children were less likely to send an international migrant (Nawrotzki et al., 2013; Massey and Riosmena, 2010). Similarly, employment in a white-collar occupation reduced the odds of sending a migrant internationally, confirming prior research that Mexican migrants coming to the U.S. are mostly young, uneducated males (Massey et al., 1987; Fussell, 2004). Reflecting the importance of social networks, community-based prevalence of adults with migration experience is consistently among the strongest international migration predictors (Fussell and Massey, 2004; Massey, 1990).

A few predictors differed between the first and last migration. A household might use initial migration (first move) to obtain the necessary funding to start a business (Massey and Parrado, 1998). Households already in possession of a business do not need to draw on migration to fund a business startup and are therefore less likely to send a migrant. In contrast, after a successful first move and business formation, the likelihood of a consecutive move is no longer determined by physical capital but rather through internal social networks (c.f., Massey and 
Espinosa, 1997). Working experience only matters for the first move with higher levels of working experience reducing the odds of an international move. In addition, baseline temperature is only a significant predictor for the first move, providing initial evidence that environmental factors may matter more for the first than the last move (Henry et al., 2004). Overall, the observed effects of the control variables largely display the directionality anticipated by theoretical considerations and prior research on Mexican migration (Massey and Espinosa, 1997; Massey, 1987b; Massey and Riosmena, 2010; Taylor et al., 1996). As such, the modeling platform can be judged as a robust tool to test the effect of climate change on the first and last move. In the next analytical step, we added one climate change index at a time to the fully adjusted multi-level event-history model (Table 5).

(Table 5 about here)

Table 5 shows that 9 out of $15(60 \%)$ climate change indices are significantly associated with a first move. In contrast, only two out of 15 (13\%) indices are significantly associated with a last move. Therefore, based on a simple comparison of the number of significant effects, the analysis provides evidence that climate change more strongly impacts first compared to last international moves from rural Mexico. This supports the suppression mechanism, suggesting that the first move is a livelihood strategy more directly linked to changes in the climate while for later moves, these external triggers have less importance (c.f., de Janvry et al., 1997). Householdspecific social networks, established after the first move, therefore appear to uncouple migration decisions from climate change effects. The household specific social networks may have been used to gain knowledge and resources (e.g., remittances) to adopt farming techniques more 
robust to climate effects (Adger, 2003). Households with more stable livelihoods do not need to modify their migration behavior (either increase or decrease migration) in response to weather patterns and climatic extremes (Warner and van der Geest, 2013), resulting in largely insignificant climate change coefficients for the last move.

The directionality of the climate change effects is largely in the anticipated direction. In general, a warming trend in both high and low temperature extremes leads to higher migration probabilities. For example, an increase in the warm spell duration by one standard deviation unit increases the odds of a first move by $23 \%$ (Odd Ratio $[\mathrm{OR}]=1.23$ ). Prior research has demonstrated the adverse impact of a rising temperatures on agricultural production and farm profits (Mueller et al., 2014). For instance, corn - Mexico's primary staple crop (Keleman et al., 2009) - is particularly sensitive to high temperature extremes during certain stages in the growing cycle such as anthesis (flowering) and pollination (Schoper et al., 1987; Tollenaar and Bruulsema, 1988). The trend observed for high temperature extremes is similar evident for low temperature extremes. A warming trend leads to more outmigration (e.g., increase in the temperature of the coldest day) while a cooling trend results in a decline in outmigration (e.g., increase in the percentage of cool days).

For the last move, a significant temperature effect emerged for the temperature during the warmest night. In contrast to the uniform trend for the first move, for which warmer temperatures lead to higher outmigration rates, the opposite is the case for the last move and a warming trend is associated with a decline in outmigration. This effect may be explained with reference to the suppression mechanism, assuming that social capital facilitates climate change adaptation. Under conditions of improved climate change resilience (e.g., use of drought resistant crop, irrigation systems, etc.), an increase in temperature is not necessary problematic and may 
even be beneficial. For example, when sufficient water supply is guaranteed, an increase in temperature may increase plant metabolism and extend the growing season (Mendelsohn, 2007; Sanchez et al., 2014) and may therefore increase agriculture production and income. In such a situation, farmers may reduce the number of members send to an international destination and request all capable labor to work on the local farm, which could explain the negative temperature effect on the last move.

The general trend among precipitation indices suggests that an increase in high precipitation extremes in the semi- to very-dry Mexican context has beneficial livelihood effects, leading to a decline in the odds of a first international move. For example, an increase of one standard deviation in total wet-day precipitation decreased the odds of a first international move by $19 \%(\mathrm{OR}=0.81)$. Water is necessary for various plant metabolic functions and sufficient amounts of precipitation are necessary for positive crop yields (Cakir, 2004; Payero et al., 2006; Steduto et al., 2012). The observed effect is in line with prior research from Mexico, suggesting that more rainfall results in less international migration (Hunter et al., 2013; Nawrotzki et al., 2013).

However, the wet spell duration index provide an exception to this general trend and suggests the existence of non-linear threshold effects as observed in prior research (Nawrotzki et al., 2013). Although an increase in precipitation may be initially beneficial, long wet spells may result in flooding and waterlogging. Waterlogging negatively impacts plants metabolic activities through a reduction in nutrients uptake (Ashraf and Habib-ur-Rehman, 1999; Zaidi et al., 2003), increased risk of plant disease and insect infestation (c.f., Kozdroj and van Elsas, 2000), and delayed planting or harvesting due to inability to operate machinery. Growing-season precipitation and harvest yield are non-linearly related with a decline in crop-yield when 
cumulative precipitation exceeds $500 \mathrm{~mm}$ (Rosenzweig et al., 2002). Our results suggest that households may respond with an increase in international migration if flooding results in negative livelihood outcomes. The dry spell duration index, as the inverse measure of wet spell duration, similarly indicates that the absence of flooding (e.g., during times of longer dry spells) is beneficial for rural livelihoods. Dry and warm conditions during the harvest period facilitate operation of harvest machinery, prevent water damage to crops (e.g., mold), and reduce costs of crop drying (c.f., Abawi et al., 1995).

While an increase in the length of wet periods negatively impacted livelihoods during the first move, such changes appeared to be beneficial for households with access to internal social capital, as evident by a decline in the odds of a last international move. Assuming that internal social capital facilitates climate change adaptation, these households may have installed drainage systems and build water cisterns to turn long rain periods into an advantage and store rainwater for dry seasons (c.f., Adger et al., 2005).

In short, the results suggest that the first move is most sensitive to climate change effects and an increase in temperature and a decline in precipitation generally lead to an increase in first international outmigration. However, the relationship between precipitation and livelihoods is bound by thresholds and flooding may similarly lead to an increase in outmigration. In contrast, the last move is largely insensitive to climate factors potentially due to social capital-mediated climate change adaptation and more robust livelihoods.

In the next step of the analysis, we investigated whether the access to community social networks encourages (amplification mechanism) or impedes (suppression mechanism) climate change-related migration. To this end we interacted each climate change index with the community migrant prevalence measure (Table 6). Table 6 reveals two significant interactions, 
which emerge for the first international move in relation to changes in temperature extremes. The sign of the interaction coefficient (CCI $x$ IntMig) are the opposite of the climate change main effect $(C C I)$, indicating that an increase in community social networks suppresses climate effects.

(Table 6 about here)

(Figure 4 about here)

Figure 4 illustrates that an increase in temperature leads to the strongest increase (steepest slope) in the probability of a first international move when households have only limited access to community migrant networks (dotted line). However, this relationship declines with better access to migrant networks and communities with the strongest migrant networks show the weakest association with international outmigration.

Much in line with the results from the investigation of household level social capital (first vs. last move), the interaction models suggest that community level social capital suppresses the effect of climate change on migration. As suggested by the suppression mechanism, the social ties as well as the resources available through social networks may facilitate climate change adaptation and build resilience at home (Adger, 2003; Pelling and High, 2005). Households may learn from their successful migrant neighbors how to adjust farming techniques, use technology (irrigation, drought resistant crops), set up informal risk-sharing institutions, or access microloans in order to become less vulnerable to the effects of climate change. In addition, remittances channeled through social networks may provide the financial capital necessary to implement technology-based adaptation strategies. Alternatively to a more direct suppression mechanism 
leading to beneficial effects of social networks for climate change adaptation, the observed interaction could be caused by social capital exhaustion. That is, communities with very dense migrant networks may have less social capital available to potential migrants if the context of reception faced by community members is unfavorable (c.f., Menjivar, 2000) and/or networks are closed and lack a continuous inflow of social capital (the so-called strength of weak ties, see Granovetter 1983). However, we believe the suppression mechanism is more likely to be operating given that the main effect of migrant networks is strong and positive.

\section{Conclusion}

Making use of a novel set of 15 ETCCDI climate change indices, we examined the effect of household and community specific social networks on climate-related migration. Some researchers have proposed that migrant networks may operate as "migrant corridors" and may facilitate large-scale international migration in the face of climatic strain (e.g., Bardsley and Hugo, 2010). However, this study suggests that these assumptions do not appropriately reflect the climate change-migration dynamics for Mexico during 1986-99. Rather, we find that migrant networks at the community and household level weakened the effect of climate change on international migration. As such the findings support a suppression mechanism rather than an amplification mechanism, suggesting social networks may facilitate climate change adaptation at home (Adger, 2003; Pelling and High, 2005) and thereby reduce the importance of climate change as migration driver.

This study is limited in its generalizability due to the selective nature of the employed migration data and applies predominantly to the study communities for the years 1986-99. An additional challenge lies in the data construction, since interpolation and imputation techniques 
may have resulted in data smoothing and an underestimation of the naturally occurring variation. Finally, the employed climate change indices reflect annual aggregates and may not appropriately reflect seasonal effects that may be of importance for the agricultural sector.

Despite these limitations, this study contributes substantially to our understanding of the climate change-migration relationship. We argue that alarmist assumptions of massive, social network-based, climate migration scenarios should be critically assessed and consider that networks may not always have multiplier effects on migration. The possibility of a "suppression mechanism" whereby social networks facilitate climate change adaptation at home and reduce the influence of environmental factors should be considered both within policy and future research. Programs designed to reduce climate related migration may usefully consider fostering existing migrant networks and engaging them as a channel for dissemination of information and resources (e.g., remittances) for climate change adaptation in origin communities.

\section{References}

Abawi, G. Y., Smith, R. J., \& Brady, D. K. (1995). Assessment of the value of long-range weather forecasts in wheat harvest management. Journal of Agricultural Engineering Research, 62(1), 39-48. doi:10.1006/jaer.1995.1061

Adamo, S. B., \& de Sherbinin, A. (2011). The impact of climate change on the spatial distribution of populations and migration Population distribution, urbanization, internal migration and development: An international perspective (pp. 161-195). New York: Unite Nations, Department of Economic and Social Affairs, Population Division.

Adger, W. N. (2003). Social capital, collective action, and adaptation to climate change. Economic Geography, 79(4), 387-404.

Adger, W. N., Arnell, N. W., \& Tompkins, E. L. (2005). Successful adaptation to climate change across scales. Global Environmental Change-Human and Policy Dimensions, 15(2), 77 86. doi:10.1016/j.gloenvcha.2004.12.005

Alexander, L. V., Zhang, X., Peterson, T. C., Caesar, J., Gleason, B., Tank, A., . . VazquezAguirre, J. L. (2006). Global observed changes in daily climate extremes of temperature 
and precipitation. Journal of Geophysical Research-Atmospheres, 111(D5), 22. doi:10.1029/2005jd006290

Allison, P. (1984). Event history analysis. Thousand Oaks, CA: Sage Publications.

Allison, P. D. (2002). Missing data. Thousand Oaks, CA: Sage Publications.

Ashraf, M., \& Habib-ur-Rehman. (1999). Interactive effects of nitrate and long-term waterlogging on growth, water relations, and gaseous exchange properties of maize (Zea mays L.). Plant Science, 144(1), 35-43. doi:10.1016/s0168-9452(99)00055-2

Aznar, J. C., Gloaguen, E., Tapsoba, D., Hachem, S., Caya, D., \& Begin, Y. (2013). Interpolation of monthly mean temperatures using cokriging in spherical coordinates. International Journal of Climatology, 33(3), 758-769. doi:10.1002/joc.3468

Barber, J. S., Murphy, S. A., Axinn, W. G., \& Maples, J. (2000). Discrete-time multilevel hazard analysis. Sociological Methodology, 30(1), 201-235.

Bardsley, D. K., \& Hugo, G. J. (2010). Migration and climate change: examining thresholds of change to guide effective adaptation decision-making. Population and Environment, 32(2-3), 238-262. doi:10.1007/s11111-010-0126-9

Bates, D., Maechler, M., Bolker, B. M., \& Walker, S. (2014). Ime4: Linear mixed-effects models using Eigen and S4. Retrieved from

Bates, D. M. (2010). lme4: Mixed-effects modeling with R. New York: Springer.

Bindoff, N. L., Stott, P. A., Achutarao, K. M., Allen, M. R., Gillett, N., Gutzler, D., . . Zhang, X. (2013). Detection and attribution of climate change: from global to regional. In T. F. Stocker, D. Qin, G. K. Plattner, M. Tignor, S. K. Allen, J. Boschung, A. Nauels, Y. Xia, V. Bex, \& P. M. Midgley (Eds.), Climate change 2013: The physical science basis. Contribution of working group 1 to the fifth assessment report of the Intergovernmental Panel on Climate Change. New York: Cambridge University Press.

Bolstad, P. (2012). GIS Fundamentals: A first text on Geographic Information Systems (4 ed.). White Bear Lake, MN: Eider Press.

Bronaugh, D. (2014). $R$ package climdex.pcic: PCIC implementation of Climdex routines. Victoria, British Columbia, Canada: Pacific Climate Impact Consortium.

Caesar, J., Alexander, L., \& Vose, R. (2006). Large-scale changes in observed daily maximum and minimum temperatures: Creation and analysis of a new gridded data set. Journal of Geophysical Research-Atmospheres, 111(D5). doi:10.1029/2005jd006280 
Cakir, R. (2004). Effect of water stress at different development stages on vegetative and reproductive growth of corn. Field Crops Research, 89(1), 1-16.

doi:10.1016/j.fcr.2004.01.005

Carney, D., Drinkwater, M., Rusinow, T., Neefjes, K., Wanmali, S., \& Singh, N. (1999). Livelihoods approaches compared. London: Department for International Development.

Carr, D. L., Lopez, A. C., \& Bilsborrow, R. E. (2009). The population, agriculture, and environment nexus in Latin America: country-level evidence from the latter half of the twentieth century. Population and Environment, 30(6), 222-246. doi:10.1007/s11111009-0090-4

Cohen, J. H. (2004). The culture of migration in Southern Mexico. Austin, TX: University of Texas Press.

Cornelius, W. A. (1992). From sojourners to settlers: The changing profile of Mexican migration to the United States. In J. A. Bustamante, C. W. Reynolds, \& R. A. Hinojosa Ojeda (Eds.), U.S.-Mexico relations: Labor market interdependence (pp. 155-195). Stanford, CA: Stanford University Press.

Curran, S. R., \& Rivero-Fuentes, E. (2003). Engendering migrant networks: The case of Mexican migration. Demography, 40(2), 289-307. doi:10.2307/3180802

Danielson, J. J., \& Gesch, D. B. (2011). Global multi-resolution terrain elevation data 2010 (GMTED2010): Open-File Report 2011-1073. Retrieved from Reston, Virginia:

Davis, B., Stecklov, G., \& Winters, P. (2002). Domestic and international migration from rural Mexico: Disaggregating the effects of network structure and composition. Population Studies-a Journal of Demography, 56(3), 291-309. doi:10.1080/00324720215936

de Janvry, A., \& Sadoulet, E. (2001). Income strategies among rural households in Mexico: The role of off-farm activities. World Development, 29(3), 467-480.

de Janvry, A., Sadoulet, E., Davis, B., Seidel, K., \& Winters, P. (1997). Determinants of MexicoU.S. migration: The role of household assets and environmental factors. Retrieved from Berkley, CA:

Donat, M. G., Alexander, L. V., Yang, H., Durre, I., Vose, R., Dunn, R. J. H., . . Kitching, S. (2013). Updated analyses of temperature and precipitation extreme indices since the beginning of the twentieth century: The HadEX2 dataset. Journal of Geophysical Research-Atmospheres, 118(5), 2098-2118. doi:10.1002/jgrd.50150

Durand, J., \& Massey, D. S. (2003). Clandestionos: Migracion Mexico-Estados Unidos en los Albores del Siglo XXI. Zacatecas, Mexico: Universidad Autonoma de Zacatecas. 
Eakin, H. (2005). Institutional change, climate risk, and rural vulnerability: Cases from central Mexico. World Development, 33(11), 1923-1938. doi:10.1016/j.worlddev.2005.06.005

Feng, S., \& Oppenheimer, M. (2012). Applying statistical models to the climate-migration relationship. Proceedings of the National Academy of Science, 109(43), E2915.

Fussell, E. (2004). Sources of Mexico's migration stream: Rural, urban, and border migrants to the United States. Social Forces, 82(3), 937-967. doi:10.1353/sof.2004.0039

Fussell, E., \& Massey, D. S. (2004). The limits to cumulative causation: International migration from Mexican urban areas. Demography, 41(1), 151-171.

Garzon-Machado, V., Otto, R., \& Aguilar, M. J. D. (2014). Bioclimatic and vegetation mapping of a topographically complex oceanic island applying different interpolation techniques. International Journal of Biometeorology, 58(5), 887-899. doi:10.1007/s00484-013-0670$\mathrm{y}$

Granovetter, M. (1983). The strength of weak ties: A network theory revisited. Sociological Theory, 1, 201-233.

Gray, C., \& Bilsborrow, R. (2013). Environmental Influences on Human Migration in Rural Ecuador. Demography, 50, 1217-1241. doi:10.1007/s13524-012-0192-y

Gray, C., \& Mueller, V. (2012). Drought and Population Mobility in Rural Ethiopia. World Development, 40(1), 134-145. doi:10.1016/j.worlddev.2011.05.023

Gray, C. L. (2009). Environment, Land, and Rural Out-migration in the Southern Ecuadorian Andes. World Development, 37(2), 457-468. doi:10.1016/j.worlddev.2008.05.004

Gray, C. L. (2010). Gender, natural capital, and migration in the southern Ecuadorian Andes. Environment and Planning, 42, 678-696.

Gubert, F. (2002). Do migrants insure those who stay behind? Evidence from the Kayes Area (Western Mali). Oxford Development Studies, 30(3), 267-287.

Gutmann, M. P., \& Field, V. (2010). Katrina in historical context: environment and migration in the US. Population and Environment, 31(1-3), 3-19. doi:10.1007/s11111-009-0088-y

Hamilton, E. R., \& Villarreal, A. (2011). Development and the Urban and Rural Geography of Mexican Emigration to the United States. Social Forces, 90(2), 661-683. doi:10.1093/sf/sor011

Henry, S., Schoumaker, B., \& Beauchemin, C. (2004). The impact of rainfall on the first outmigration: A multi-level event-history analysis in Burkina Faso. Population and Environment, 25(5), 423-460. 
Hevesi, J. A., Istok, J. D., \& Flint, A. L. (1992). Precipitation estimation in mountainous terrain using multivariate geostatistics .1. Structural-analysis. Journal of Applied Meteorology, 31(7), 661-676. doi:10.1175/1520-0450(1992)031<0661:peimtu>2.0.co;2

Honaker, J., \& King, G. (2010). What to Do about Missing Values in Time-Series Cross-Section Data. American Journal of Political Science, 54(2), 561-581.

Honaker, J., King, G., \& Blackwell, M. (2011). Amelia II: A Program for Missing Data. Journal of Statistical Software, 45(7), 1-47.

Hunter, L. M., Murray, S., \& Riosmena, F. (2013). Rainfall patterns and U.S. migration from rural Mexico. International Migration Review, 47(4), 874-909.

Hunter, L. M., \& O'Neill, B. C. (2014). Enhancing engagement between the population, environment, and climate research communities: the shared socio-economic pathway process. Population and Environment, 35(3), 231-242. doi:10.1007/s11111-014-0202-7

Huq, S., Rahman, A., Konate, M., Sokona, Y., \& Reid, H. (2003). Mainstreaming adaptation to climate change in least developed countries (LDCs). Retrieved from London:

INEGI. (2012). Sistema Estatal y Municipal de Bases de Datos. Aguascalientes, Mexico: Instituto Nacional de Estadística, Geografía e Informática, Retrieved July 4, 2012 from http://sc.inegi.org.mx/sistemas/cobdem/primeraentrada.do? $\mathrm{w}=25 \&$ Backidhecho $=302 \& \mathrm{Ba}$ ckconstem $=301 \&$ constembd $=165$.

IPCC. (2013). Summary for Policymakers. In T. F. Stocker, D. Qin, G. K. Plattner, M. Tignor, S. K. Allen, J. Boschung, A. Nauels, Y. Xia, V. Bex, \& P. M. Midgley (Eds.), Climate Change 2013: The Physical Science Basis. Contribution of Working Group 1 to the Fifth Assessment Report of the Intergovernmental Panel on Climate Change (pp. 1-28). New York: Cambridge University Press.

IPCC. (2014). Summary for policymakers. In C. B. Field, V. R. Barros, D. J. Dokken, K. J. Mach, M. D. Mastrandrea, T. E. Bilir, M. Chatterjee, K. L. Ebi, Y. O. Estrada, R. C. Genova, B. Girma, E. S. Kissel, A. N. Levy, S. MacCracken, P. r. Mastrandrea, \& L. L. White (Eds.), Climate Change 2014: Impacts, Adaptation, and Vulnerability. Part A: Global and Sectoral Aspects. Contribution of Working Group 2 to the Fifth Assessment Report of the Intergovernmental Panel on Climate Change (pp. 1-32). New York: Cambridge University Press.

Keleman, A., Hellin, J., \& Bellon, M. R. (2009). Maize diversity, rural development policy, and farmers' practices: lessons from Chiapas, Mexico. Geographical Journal, 175, 52-70. doi:10.1111/j.1475-4959.2008.00314.x

Klein Tank, A. M. G., Peterson, T. C., Quadir, D. A., Dorji, S., Zou, X., Tang, H., . . . Spektorman, T. (2006). Changes in daily temperature and precipitation extremes in 
central and south Asia. Journal of Geophysical Research-Atmospheres, 111(D16). doi:10.1029/2005jd006316

Kozdroj, J., \& van Elsas, J. D. (2000). Response of the bacterial community to root exudates in soil polluted with heavy metals assessed by molecular and cultural approaches. Soil Biology \& Biochemistry, 32(10), 1405-1417. doi:10.1016/s0038-0717(00)00058-4

Lindstrom, D. P., \& Lauster, N. (2001). Local economic opportunity and the competing risks of internal and US migration in Zacatecas, Mexico. International Migration Review, 35(4), 1232-1256.

Little, R. J. A., \& Rubin, D. B. (2002). Statistical analysis with missing data (2nd edition ed.). New York: John Wiley and Sons.

Lobell, D. B., \& Field, C. B. (2007). Global scale climate - crop yield relationships and the impacts of recent warming. Environmental Research Letters, 2(1). doi:10.1088/1748$9326 / 2 / 1 / 014002$

LoBreglio, K. (2004). The border security and immigration improvement act a modern solution to a historic problem. St. John's Law Review, 78(3), 933-963.

Lustig, N. (1990). Economic-crisis, adjustment and living standards in Mexico, 1982-85. World Development, 18(10), 1325-1342. doi:10.1016/0305-750x(90)90113-c

Martin, P. L. (1990). Harvest of confusion - immigration reform and California agriculture. International Migration Review, 24(1), 69-95. doi:10.2307/2546672

Massey, D., \& Aysa-Lastra, M. (2011). Social capital and international migration from Latin America. International Journal of Population Research, 2011, 1-18.

Massey, D. S. (1987a). The Ethnosurvey in theory and practice. International Migration Review, 21(4), 1498-1522. doi:10.2307/2546522

Massey, D. S. (1987b). Understanding Mexican migration to the United-States. American Journal of Sociology, 92(6), 1372-1403. doi:10.1086/228669

Massey, D. S. (1990). Social-structure, household strategies, and the cumulative causation of migration. Population Index, 56(1), 3-26.

Massey, D. S., Alarcon, R., Durand, J., \& Gonzalez, H. (1987). Return to Aztlan: The social process of international migration from Western Mexico. Berkely, CA: University of California Press.

Massey, D. S., Arango, J., Hugo, G., Kouaouci, A., Pellegrino, A., \& Taylor, J. E. (1993). Theories of international migration - A review and appraisal. Population and Development Review, 19(3), 431-466. 
Massey, D. S., Axinn, W. G., \& Ghimire, D. J. (2010). Environmental change and out-migration: evidence from Nepal. Population and Environment, 32(2-3), 109-136. doi:10.1007/s11111-010-0119-8

Massey, D. S., \& Capoferro, C. (2004). Measuring undocumented migration. International Migration Review, 38(3), 1075-1102.

Massey, D. S., Durand, J., \& Malone, N. J. (2002). Beyond smoke and mirrors: Mexican immigration in an era of economic integration. New York: Russell Sage Foundation Publications.

Massey, D. S., Durand, J., \& Pren, K. A. (2015). Border Enforcement and Return Migration by Documented and Undocumented Mexicans. Journal of Ethnic and Migration Studies, 41(7), 1015-1040. doi:10.1080/1369183x.2014.986079

Massey, D. S., \& Espinosa, K. E. (1997). What's driving Mexico-US migration? A theoretical, empirical, and policy analysis. American Journal of Sociology, 102(4), 939-999.

Massey, D. S., \& Garcia Espana, F. (1987). The social process of international migration. Science, 237(4816), 733-738. doi:10.1126/science.237.4816.733

Massey, D. S., \& Parrado, E. A. (1998). International migration and business formation in Mexico. Social Science Quarterly, 79(1), 1-20.

Massey, D. S., \& Riosmena, F. (2010). Undocumented migration from Latin America in an era of rising U.S. enforcement. Annals of the American Academy of Political and Social Science, 630, 294-321.

Massey, D. S., \& Zenteno, R. (2000). A validation of the ethnosurvey: The case of Mexico-US migration. International Migration Review, 34(3), 766-793. doi:10.2307/2675944

Matheron, G. (1971). The theory of regionalized variables and its applications. Paris, France: Ecole Nationale Superieur des Mines de Paris.

McKenzie, D. J. (2006). The consumer response to the Mexican peso crisis. Economic Development and Cultural Change, 55(1), 139-172. doi:10.1086/505721

McLeman, R., \& Smit, B. (2006). Migration as an adaptation to climate change. Climatic Change, 76(1-2), 31-53. doi:10.1007/s10584-005-9000-7

Mendelsohn, R. (2007). What causes crop failure? Climatic Change, 81(1), 61-70. doi:10.1007/s10584-005-9009-y

Menjivar, C. (2000). Fragmented ties: Salvadoran immigrant networks in America. Berkely, CA: University of California Press. 
Menne, M. J., Durre, I., Vose, R. S., Gleason, B. E., \& Houston, T. G. (2012). An Overview of the Global Historical Climatology Network-Daily Database. Journal of Atmospheric and Oceanic Technology, 29(7), 897-910. doi:10.1175/jtech-d-11-00103.1

MPC. (2013). Integrated Public Use Microdata Series, International: Version 6.2 [Machinereadable database ]. Minneapolis, MA: University of Minnesota.

Mueller, V., Gray, C., \& Kosec, K. (2014). Heat stress increases long-term human migration in rural Pakistan. Nature Climate Change, 4(3), 182-185. doi:10.1038/nclimate2103

Munshi, K. (2003). Networks in the modern economy: Mexican migrants in the US labor market. Quarterly Journal of Economics, 118(2), 549-599. doi:10.1162/003355303321675455

Nawrotzki, R. J. (2012). The politics of environmental concern: A cross-national analysis. Organization \& Environment, 25(3), 286-307. doi:10.1177/1086026612456535

Nawrotzki, R. J., Riosmena, F., \& Hunter, L. M. (2013). Do rainfall deficits predict U.S.-bound migration from rural Mexico? Evidence from the Mexican census. Population Research and Policy Review, 32(1), 129-158. doi:10.1007/s11113-012-9251-8

Orrenius, P. M., \& Zavodny, M. (2003). Do amnesty programs reduce undocumented immigration? Evidence from IRCA. Demography, 40(3), 437-450. doi:10.2307/1515154

Payero, J. O., Melvin, S. R., Irmak, S., \& Tarkalson, D. (2006). Yield response of corn to deficit irrigation in a semiarid climate. Agricultural Water Management, 84(1-2), 101-112. doi:10.1016/j.agwat.2006.01.009

Pelling, M., \& High, C. (2005). Understanding adaptation: What can social capital offer assessments of adaptive capacity? Global Environmental Change-Human and Policy Dimensions, 15(4), 308-319. doi:10.1016/j.gloenvcha.2005.02.001

Peterson, T. C., Folland, C., Gruza, G., Hogg, W., Mokssit, A., \& Plummer, N. (2001). Report of the activities of the working group on climate change detection and related rapporteurs. Retrieved from Geneva, Switzerland:

Peterson, T. C., \& Manton, M. J. (2008). Monitoring changes in climate extremes - A tale of international collaboration. Bulletin of the American Meteorological Society, 89(9), 12661271. doi:10.1175/2008bams2501.1

Pretty, J., \& Ward, H. (2001). Social capital and the environment. World Development, 29(2), 209-227. doi:10.1016/s0305-750x(00)00098-x

RCoreTeam. (2014). $R$ : A language and environment for statistical computing. Vienna, Austria: R Foundation for Statistical Computing, http://www.R-project.org/. 
Riosmena, F. (2004). Return Versus Settlement Among Undocumented Mexican Migrants, 1980 to 1996. In J. Durand \& D. S. Massey (Eds.), Crossing the Border: Research from the Mexican Migration Project (pp. 265-280). New York: Russell Sage Foundation.

Riosmena, F. (2009). Socioeconomic context and the association between marriage and MexicoUS migration. Social Science Research, 38(2), 324-337. doi:10.1016/j.ssresearch.2008.12.001

Rosenzweig, C., Tubiello, F. N., Goldberg, R., Mills, E., \& Bloomfield, J. (2002). Increased crop damage in the US from excess precipitation under climate change. Global Environmental Change-Human and Policy Dimensions, 12(3), 197-202. doi:10.1016/s09593780(02)00008-0

Rubin, D. (1987). Multiple imputation for nonresponse in surveys. New York: Wiley.

Ruggles, S., King, M. L., Levison, D., McCAA, R., \& Sobek, M. (2003). IPUMS-International. Historical Methods, 36(2), 60-65.

Ruiter, S., \& De Graaf, N. D. (2006). National context, religiosity, and volunteering: Results from 53 countries. American Sociological Review, 71(2), 191-210.

Saldana-Zorrilla, S. O., \& Sandberg, K. (2009). Spatial econometric model of natural disaster impacts on human migration in vulnerable regions of Mexico. Disasters, 33(4), 591-607. doi:10.1111/j.0361-3666.2008.01089.x

Sanchez, B., Rasmussen, A., \& Porter, J. R. (2014). Temperatures and the growth and development of maize and rice: a review. Global Change Biology, 20(2), 408-417. doi:10.1111/gcb.12389

Schoper, J. B., Lambert, R. J., \& Vasilas, B. L. (1987). Pollen viability, pollen shedding, and combining ability for tassel heat tolerance in maize. Crop Science, 27(1), 27-31.

Scoones, I. (1999). Sustainable rural livelihoods: A framework for analysis. Brighton, U.K.: Institute of Development Studies.

Singer, J. D., \& Willett, J. B. (2003). Applied longitudinal data analysis. New York: Oxford University Press.

Stark, O., \& Bloom, D. E. (1985). The new economics of labor migration. American Economic Review, 75(2), 173-178.

Steduto, P., Hsiao, T. C., Fereres, E., \& Raes, D. (2012). Crop yield response to water. Retrieved from Rome, Italy:

Steele, F. (2005). Event history analysis. Bristol, U.K.: ESRC National Centre for Research Methods. 
Steele, F., Diamond, I., \& Amin, S. (1996). Immunization uptake in rural Bangladesh: A multilevel analysis. Journal of the Royal Statistical Society Series a-Statistics in Society, 159, 289-299. doi:10.2307/2983175

Steele, F., Goldstein, H., \& Browne, W. (2004). A general multilevel multistate competing risks model for event history data, with an application to a study of contraceptive use dynamics. Statistical Modelling, 4(2), 145-159. doi:10.1191/1471082X04st069oa

Taylor, J. E., Arango, J., Hugo, G., Kouaouci, A., Massey, D. S., \& Pellegrino, A. (1996). International migration and community development. Population Index, 62(3), 397-418. doi:10.2307/3645924

Tollenaar, M., \& Bruulsema, T. W. (1988). Efficiency of maize dry-matter production during periods of complete leaf-area expansion. Agronomy Journal, 80(4), 580-585.

Warner, K., \& van der Geest, K. (2013). Loss and damage from climate change: local-level evidence from nine vulnerable countries. International Journal of Global Warming, 5(4), 367-386. doi:10.1504/ijgw.2013.057289

Yang, D., \& Choi, H. (2007). Are remittances insurance? Evidence from rainfall shocks in the Phillipines. The World Bank Economic Review, 21(2), 219-248.

Zaidi, P. H., Rafique, S., \& Singh, N. N. (2003). Response of maize (Zea mays L.) genotypes to excess soil moisture stress: morpho-physiological effects and basis of tolerance. European Journal of Agronomy, 19(3), 383-399. doi:10.1019/s1161-0301(02)00090-4

Table 1: Subset of ETCCDI climate change indices employed for the analysis of the impact climate change on first and last international migration from rural Mexico, 1986-99

\begin{tabular}{|c|c|c|c|}
\hline & ID & Indicator definition & Unit \\
\hline \multicolumn{4}{|l|}{ Temperature (high) } \\
\hline Warm spell duration & wsdi & $\begin{array}{l}\text { Annual count when at least six consecutive days } \\
\text { of max temperature }>90 \text { th percentile }\end{array}$ & days \\
\hline Warmest day & Txx & Annual max value of daily max temperature & ${ }^{\circ} \mathrm{C}$ \\
\hline Warmest night & $\operatorname{Tnx}$ & Annual max value of daily min temperature & ${ }^{\circ} \mathrm{C}$ \\
\hline$\%$ warm nights & $\operatorname{tn} 90 p$ & $\begin{array}{l}\text { Percentage of days per year when daily min } \\
\text { temperature }>90 \text { th percentile }\end{array}$ & $\%$ \\
\hline
\end{tabular}

Temperature (low) 


\begin{tabular}{|c|c|c|c|}
\hline No. frost days & $\mathrm{fd}$ & Annual count when daily min temperature $<0^{\circ} \mathrm{C}$ & days \\
\hline Cold spell duration & csdi & $\begin{array}{l}\text { Annual count when at least six consecutive days } \\
\text { of min temperature }<10 \text { th percentile }\end{array}$ & days \\
\hline Coldest day & $\operatorname{txn}$ & Annual min value of daily max temperature & ${ }^{\circ} \mathrm{C}$ \\
\hline$\%$ cool nights & $\operatorname{tn} 10 \mathrm{p}$ & $\begin{array}{l}\text { Percentage of days per year when daily min } \\
\text { temperature }<10 \text { th percentile }\end{array}$ & $\%$ \\
\hline$\%$ cool days & $\operatorname{tx} 10 \mathrm{p}$ & $\begin{array}{l}\text { Percentage of days per year when daily max } \\
\text { temperature }<10 \text { th percentile }\end{array}$ & $\%$ \\
\hline \multicolumn{4}{|l|}{ Precipitation (high) } \\
\hline No. days very heavy precip & r20mm & Annual count of days when precip $>20 \mathrm{~mm}$ & days \\
\hline Wet spell duration & cwd & $\begin{array}{l}\text { Max number of consecutive days with precip > } \\
1 \mathrm{~mm}\end{array}$ & days \\
\hline Max 5-day precip & rx5day & Annual max consecutive 5-day precip amount & $\mathrm{mm}$ \\
\hline Precip extremely wet days & r99ptot & $\begin{array}{l}\text { Annual total precip from days when precip }>99 \text { th } \\
\text { percentile }\end{array}$ & $\mathrm{mm}$ \\
\hline Total wet-day precip & prcptot & $\begin{array}{l}\text { Annual total precip from days when precip > } 1 \\
\mathrm{~mm}\end{array}$ & $\mathrm{~mm}$ \\
\hline \multicolumn{4}{|l|}{ Precipitation (low) } \\
\hline Dry spell duration & cdd & $\begin{array}{l}\text { Max number of consecutive days when precip < } \\
1 \mathrm{~mm}\end{array}$ & days \\
\hline
\end{tabular}

Notes: A full list of the 27 ETCCDI climate change indices and their technical description can be found at http://etccdi.pacificclimate.org/list_27_indices.shtml 
Table 2: Mean values of ETCCDI climate change indices for selected years for rural Mexico

\begin{tabular}{lrrrr}
\hline & SD & \multicolumn{3}{c}{ Mean } \\
\cline { 3 - 5 } & & 1985 & 1992 & 1998 \\
\hline Temperature (high) & & & & \\
Warm spell duration & 2.22 & -0.21 & 2.09 & 6.32 \\
Warmest day & 0.81 & 0.16 & 0.27 & 0.42 \\
Warmest night & 1.02 & -0.17 & 0.38 & -0.15 \\
\% warm nights & 1.16 & -0.56 & 0.85 & 1.84 \\
Temperature (low) & & & & \\
No. frost days & 2.01 & -0.02 & -0.71 & 0.14 \\
Cold spell duration & 1.52 & 0.01 & 0.98 & 3.96 \\
Coldest day & 0.91 & -0.18 & 0.18 & 0.31 \\
\% cool nights & 0.75 & 0.41 & 0.24 & 1.60 \\
\% cool days & 0.81 & 0.43 & 0.57 & -0.23 \\
Precipitation (high) & & & & \\
No. days very heavy precip & 0.82 & 0.05 & 0.25 & -0.40 \\
Wet spell duration & 1.55 & 0.03 & 0.05 & 0.61 \\
Max 5-day precip & 0.96 & 0.04 & 0.17 & 0.12 \\
Precip extremely wet days & 1.06 & 0.10 & 0.69 & 0.73 \\
Total wet-day precip & 0.81 & 0.24 & 0.69 & -0.04 \\
Precipitation (low) & & & & \\
Dry spell duration & 0.70 & 0.08 & -0.40 & 0.23 \\
\hline
\end{tabular}

Notes: Values represent z-scores; standard deviation (SD) was computed across all years (198598); climate variables were added with a time lag of 1 year to the sociodemographic data so that, for example, the climate measures for 1985 were used to predict migration in 1986. 
Table 3: Descriptive statistics of control variables employed in the analysis of the impact of climate change on first and last international migration from rural Mexico, 1986-99

\begin{tabular}{|c|c|c|c|c|c|}
\hline & Unit & TV & Source & Mean & SD \\
\hline \multicolumn{6}{|l|}{ Household level (head) } \\
\hline \multicolumn{6}{|l|}{ Social capital } \\
\hline Female & $1 \mid 0$ & No & MMP & 0.11 & 0.32 \\
\hline Married & $1 \mid 0$ & Yes & MMP & 0.68 & 0.47 \\
\hline \multicolumn{6}{|l|}{ Human capital } \\
\hline No. of children & Count & Yes & MMP & 0.72 & 0.99 \\
\hline Education & Years & Yes & MMP & 5.62 & 4.19 \\
\hline Working experience & Years & Yes & MMP & 22.45 & 13.34 \\
\hline Occupation: not in labor force & $1 \mid 0$ & Yes & MMP & 0.09 & 0.29 \\
\hline Occupation: blue collar & $1 \mid 0$ & Yes & MMP & 0.83 & 0.37 \\
\hline Occupation: white collar & $1 \mid 0$ & Yes & MMP & 0.07 & 0.26 \\
\hline \multicolumn{6}{|l|}{ Physical capital } \\
\hline Owns property & $1 \mid 0$ & Yes & MMP & 0.60 & 0.49 \\
\hline Owns business & $1 \mid 0$ & Yes & MMP & 0.14 & 0.35 \\
\hline \multicolumn{6}{|l|}{ Community/municipality level ${ }^{\mathrm{a}}$} \\
\hline \multicolumn{6}{|l|}{ Social capital } \\
\hline International migrants & $\%$ & Yes & MMP-C & 15.53 & 14.66 \\
\hline \multicolumn{6}{|l|}{ Financial capital } \\
\hline Wealth index & z-values & Yes & IPUMS-I & -0.79 & 0.39 \\
\hline \multicolumn{6}{|l|}{ Natural capital } \\
\hline Land area planted & $\%$ & No & INEGI & 27.97 & 21.66 \\
\hline Farmland irrigated & $\%$ & No & INEGI & 23.62 & 25.68 \\
\hline Base period precip (1961-90) & $\mathrm{mm} /$ day & No & GHCN-D & 2.82 & 1.34 \\
\hline Base period temp (1961-90) & deg. C & No & GHCN-D & 21.07 & 2.93 \\
\hline \multicolumn{6}{|l|}{ Economic environment } \\
\hline Male labor in agriculture & $\%$ & Yes & MMP-C & 55.97 & 17.67 \\
\hline
\end{tabular}

Notes: $\mathrm{TV}=$ time varying $($ Yes, No); Source information: $\mathrm{MMP}=$ Mexican Migration Project data available from http://mmp.opr.princeton.edu/; MMP-C $=$ COMMUN supplementary file of MMP; IPUMS-I = Mexican census data (1\% extract) obtained via Integrated Public Use Microdata Series - International (Ruggles et al., 2003; MPC, 2013); INEGI = data obtained from Instituto Nacional de Estadística y Geografía (INEGI, 2012); GHCN-D = data derived from the Global Historical Climate Network - Daily (Menne et al., 2012); ${ }^{a}$ The percent of international migrants is measured at the community level while all other variables pertain to the municipality where the community is located. 
Table 4: Odds of a first and last international move from rural Mexican communities, 1986-99

\begin{tabular}{|c|c|c|c|c|}
\hline & \multicolumn{2}{|c|}{ First } & \multicolumn{2}{|c|}{ Last } \\
\hline & $\mathrm{b}$ & sig. & $\mathrm{b}$ & sig. \\
\hline \multicolumn{5}{|l|}{ Household level (head) } \\
\hline Female & 0.55 & $* * *$ & 0.39 & $* * *$ \\
\hline Married & 0.98 & & 0.85 & \\
\hline No. of children & 0.91 & $* *$ & 0.72 & $* * *$ \\
\hline Education (years) $^{\mathrm{a}}$ & 0.92 & & 0.97 & \\
\hline Working experience (years) ${ }^{a}$ & 0.75 & $* * *$ & 0.99 & \\
\hline Occupation: not in labor force & 0.95 & & 1.32 & \\
\hline Occupation: white collar & 0.54 & $* * *$ & 0.37 & $* *$ \\
\hline Owns property & 0.87 & & 1.20 & \\
\hline Owns business & 0.79 & $*$ & 0.87 & \\
\hline \multicolumn{5}{|l|}{ Community/municipality level } \\
\hline International migrants (\%) ${ }^{\mathrm{a}}$ & 1.51 & $* * *$ & 1.69 & $* * *$ \\
\hline Wealth index (z-values) & 1.11 & & 0.99 & \\
\hline Land area planted $(\%)^{\mathrm{a}}$ & 1.00 & & 1.03 & \\
\hline Farmland irrigated $(\%)^{\mathrm{a}}$ & 1.03 & & 0.97 & \\
\hline Base period precip (mm/day) & 1.17 & & 0.98 & \\
\hline Base period temp (deg. C) & 0.91 & $* *$ & 0.98 & \\
\hline Male labor in agriculture $(\%)^{a}$ & 1.05 & & 1.01 & \\
\hline \multicolumn{5}{|l|}{ Model statistics } \\
\hline Var. Intercept (Mun) & 0.276 & & 0.184 & \\
\hline BIC & 9275 & & 5818 & \\
\hline $\mathrm{N}$ (HH-period) & 67311 & & 90881 & \\
\hline $\mathrm{N}(\mathrm{HH})$ & 7045 & & 9580 & \\
\hline $\mathrm{N}$ (Mun) & 68 & & 68 & \\
\hline
\end{tabular}

Notes: Coefficients reflect odd ratios; all predictors were lagged by one year; low values $(<2.6$ for substantive predictors) on the variance inflation factor (VIF) suggest that multi-collinearity is of no concern; models control for baseline hazard by using fixed effects for exposure years (not 
shown); models control for survey year (not shown) to account for potential recall bias; ${ }^{\text {a }}$

Coefficients refer to an incremental change of 10 units; * $\mathrm{p}<0.05 ; * * \mathrm{p}<0.01 ; * * * \mathrm{p}<0.001$ 
Table 5: Effect of climate change indicator on the odds of a first and last international move from rural Mexican communities, 1986-99

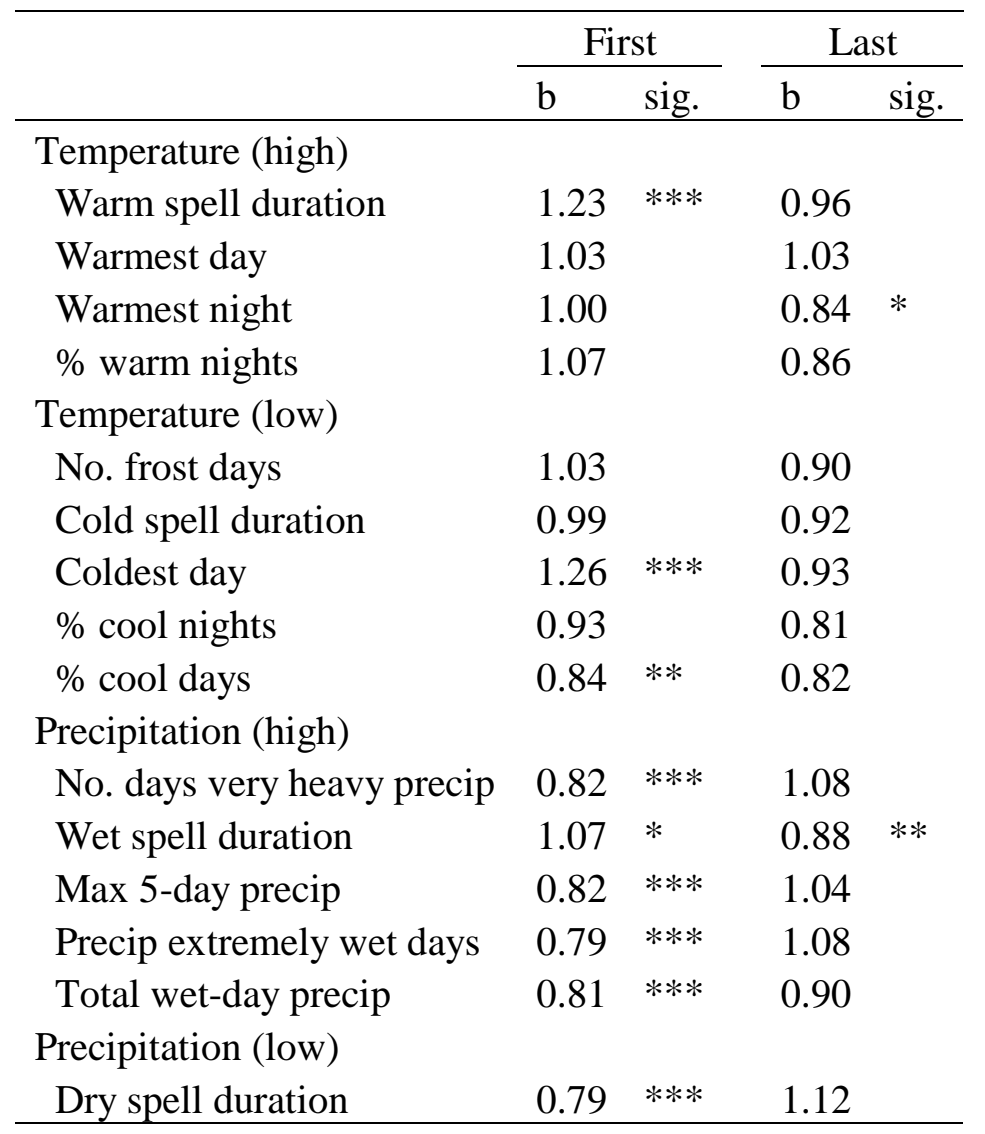

Notes: Coefficients reported in odd ratios; each coefficient was estimated using the complete set of household and municipality control variables as shown in Table 4; a jack-knife type procedure was performed to investigate the estimates' robustness by iteratively removing one municipality from the sample and re-estimating the model (Nawrotzki, 2012; Ruiter and de Graaf, 2006). The results demonstrated a high degree of robustness of the estimates;

$* \mathrm{p}<0.05 ; * * \mathrm{p}<0.01 ; * * * \mathrm{p}<0.001$ 
Table 6: Main effect and interaction between climate change and community-level international migration prevalence in predicting the odds of a first and last international move from rural Mexican communities, 1986-99

\begin{tabular}{|c|c|c|c|c|c|c|c|c|c|c|c|}
\hline & \multicolumn{6}{|c|}{ First } & \multicolumn{5}{|c|}{ Last } \\
\hline & \multicolumn{2}{|l|}{$\mathrm{CCI}$} & \multicolumn{2}{|c|}{ IntMig } & \multicolumn{2}{|c|}{ CCI x IntMig } & \multicolumn{2}{|l|}{$\mathrm{CCI}$} & \multicolumn{2}{|c|}{ IntMig } & \multirow{2}{*}{$\begin{array}{l}\text { CCI } x \\
b\end{array}$} \\
\hline & $\mathrm{b}$ & sig. & $\mathrm{b}$ & sig. & $\mathrm{b}$ & sig. & $\mathrm{b}$ & sig. & $\mathrm{b}$ & sig. & \\
\hline \multicolumn{12}{|l|}{ Temperature (high) } \\
\hline Warm spell duration & 1.21 & $* * *$ & 1.50 & $* * *$ & 0.96 & $*$ & 0.96 & & 1.68 & $* * *$ & 1.00 \\
\hline Warmest day & 1.04 & & 1.51 & $* * *$ & 1.00 & & 1.05 & & 1.69 & $* * *$ & 0.97 \\
\hline Warmest night & 0.99 & & 1.51 & $* * *$ & 1.01 & & 0.84 & $*$ & 1.70 & $* * *$ & 1.00 \\
\hline$\%$ warm nights & 1.11 & & 1.48 & $* * *$ & 0.92 & $* *$ & 0.84 & & 1.69 & $* * *$ & 1.03 \\
\hline \multicolumn{12}{|l|}{ Temperature (low) } \\
\hline No. frost days & 1.02 & & 1.51 & $* * *$ & 0.98 & & 0.94 & & 1.70 & $* * *$ & 0.95 \\
\hline Cold spell duration & 1.00 & & 1.50 & $* * *$ & 0.96 & & 0.91 & & 1.69 & $* * *$ & 1.04 \\
\hline Coldest day & 1.26 & $* * *$ & 1.52 & $* * *$ & 1.01 & & 0.95 & & 1.69 & $* * *$ & 0.98 \\
\hline$\%$ cool nights & 0.92 & & 1.51 & $* * *$ & 1.01 & & 0.83 & & 1.68 & $* * *$ & 0.98 \\
\hline$\%$ cool days & 0.81 & $* *$ & 1.50 & $* * *$ & 1.07 & & 0.82 & & 1.70 & $* * *$ & 0.99 \\
\hline \multicolumn{12}{|l|}{ Precipitation (high) } \\
\hline No. days very heavy precip & 0.83 & $* *$ & 1.51 & $* * *$ & 0.99 & & 1.14 & & 1.70 & $* * *$ & 0.96 \\
\hline Wet spell duration & 1.07 & $*$ & 1.53 & $* * *$ & 1.02 & & 0.91 & & 1.64 & $* * *$ & 0.97 \\
\hline Max 5-day precip & 0.80 & $* * *$ & 1.52 & $* * *$ & 1.03 & & 1.05 & & 1.69 & $* * *$ & 0.99 \\
\hline Precip extremely wet days & 0.80 & $* * *$ & 1.54 & $* * *$ & 1.00 & & 1.13 & & 1.70 & $* * *$ & 0.96 \\
\hline Total wet-day precip & 0.77 & $* * *$ & 1.51 & $* * *$ & 1.06 & & 0.92 & & 1.69 & $* * *$ & 0.99 \\
\hline \multicolumn{12}{|l|}{ Precipitation (low) } \\
\hline Dry spell duration & 0.81 & $* *$ & 1.56 & $* * *$ & 0.95 & & 1.14 & & 1.67 & $* * *$ & 0.99 \\
\hline
\end{tabular}

Notes: Coefficients reported in odd ratios; each row represents a full interaction model of which only the coefficients for the terms involved in the interaction are shown; $\mathrm{CCI}=$ coefficient of climate change index; IntMig = coefficient of community-level international migration prevalence; CCI x IntMig = coefficient of interaction term between CCI and IntMig; one unit reflect a $10 \%$ change in international migrant prevalence; variables were centered; 
$* \mathrm{p}<0.05 ; * * \mathrm{p}<0.01 ; * * * \mathrm{p}<0.001$ 
Figure 1: Location of rural MMP municipalities and weather stations distributed across Mexico

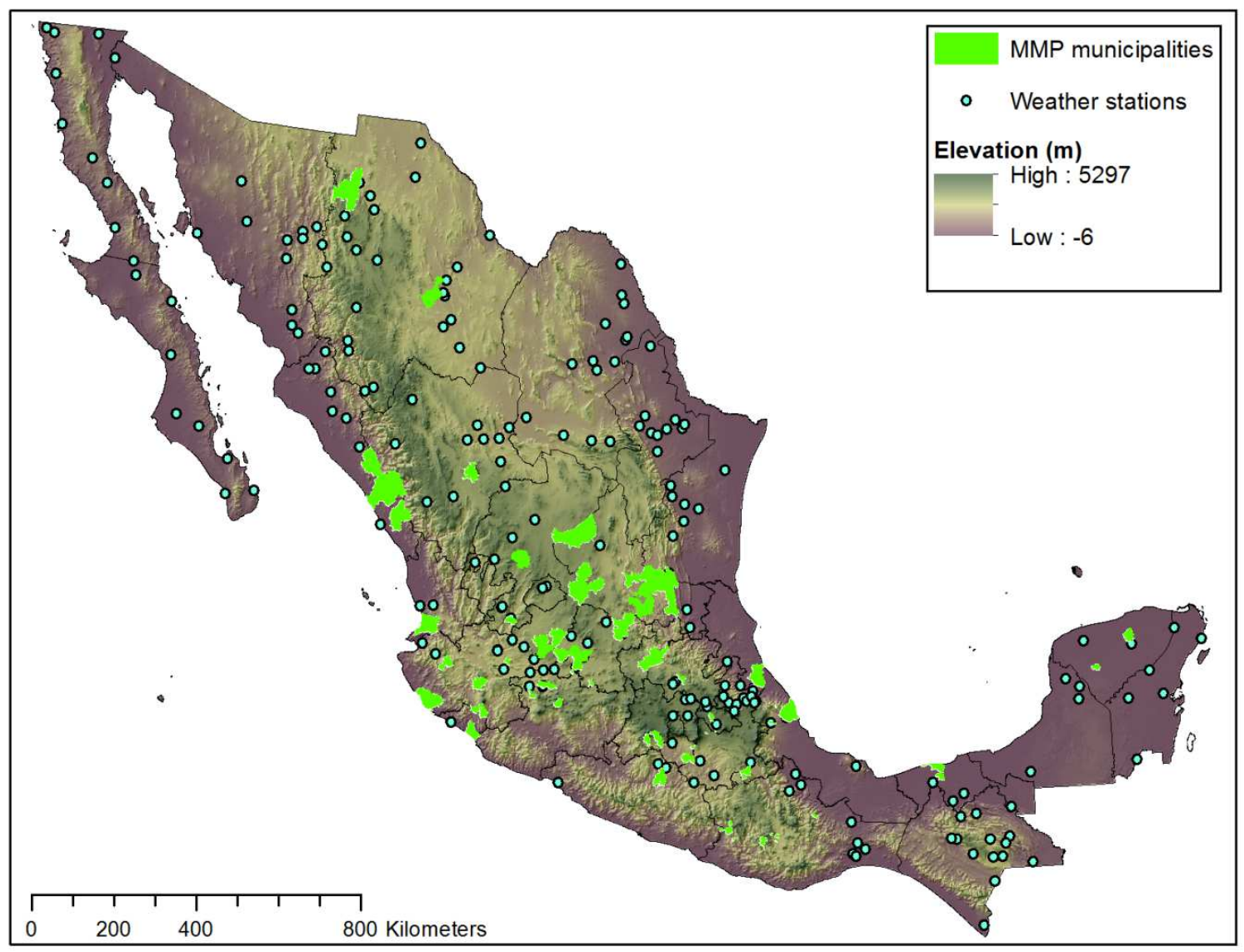


Figure 2: Hazard of first and last U.S.-bound migration for 68 rural Mexican municipalities, 1986-99

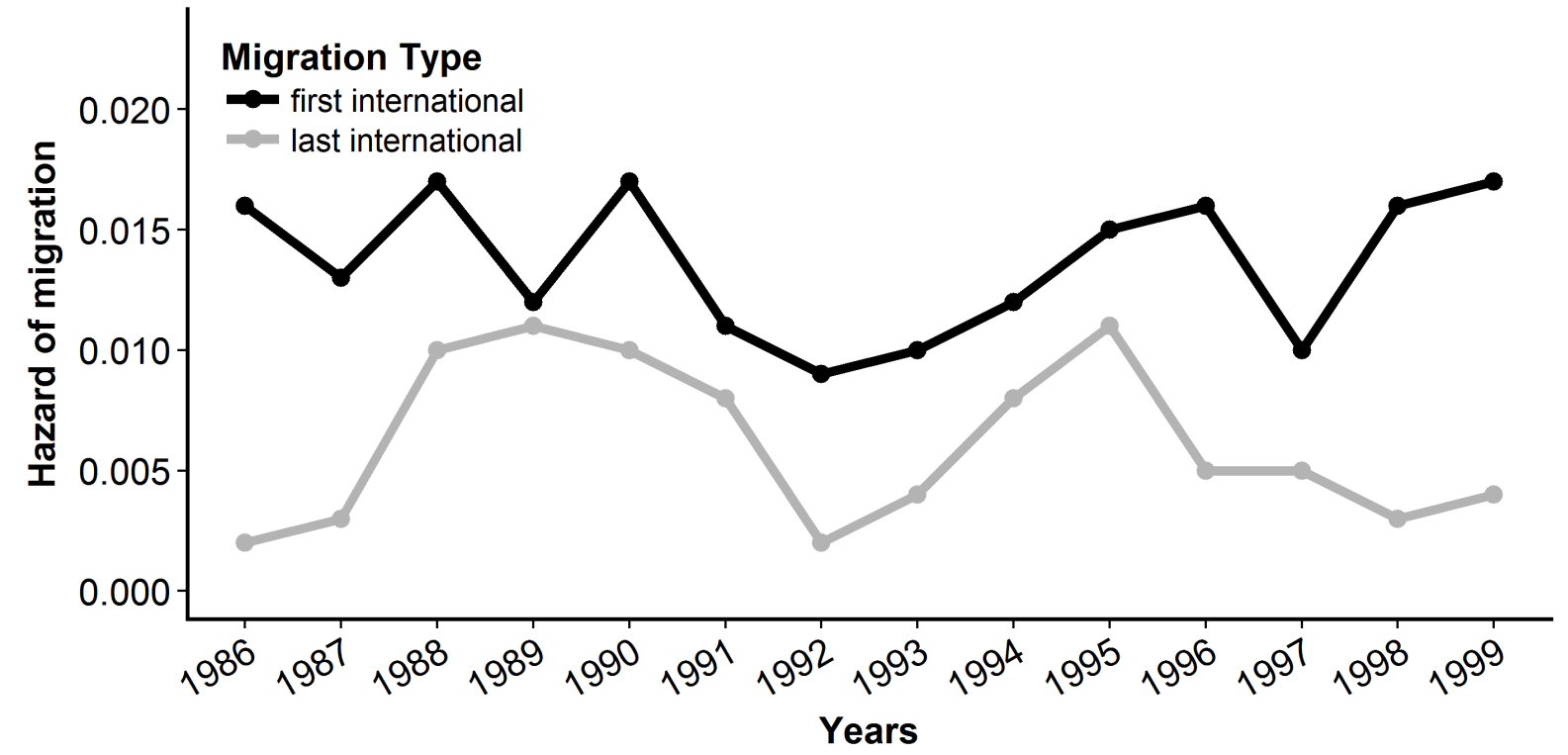

Source: Estimates based on Mexican Migration Project data. Migration hazards refer to the relevant population at risk (see Data and Methods section for more details). 
Figure 3: Visual representation of the amplification and suppression mechanism
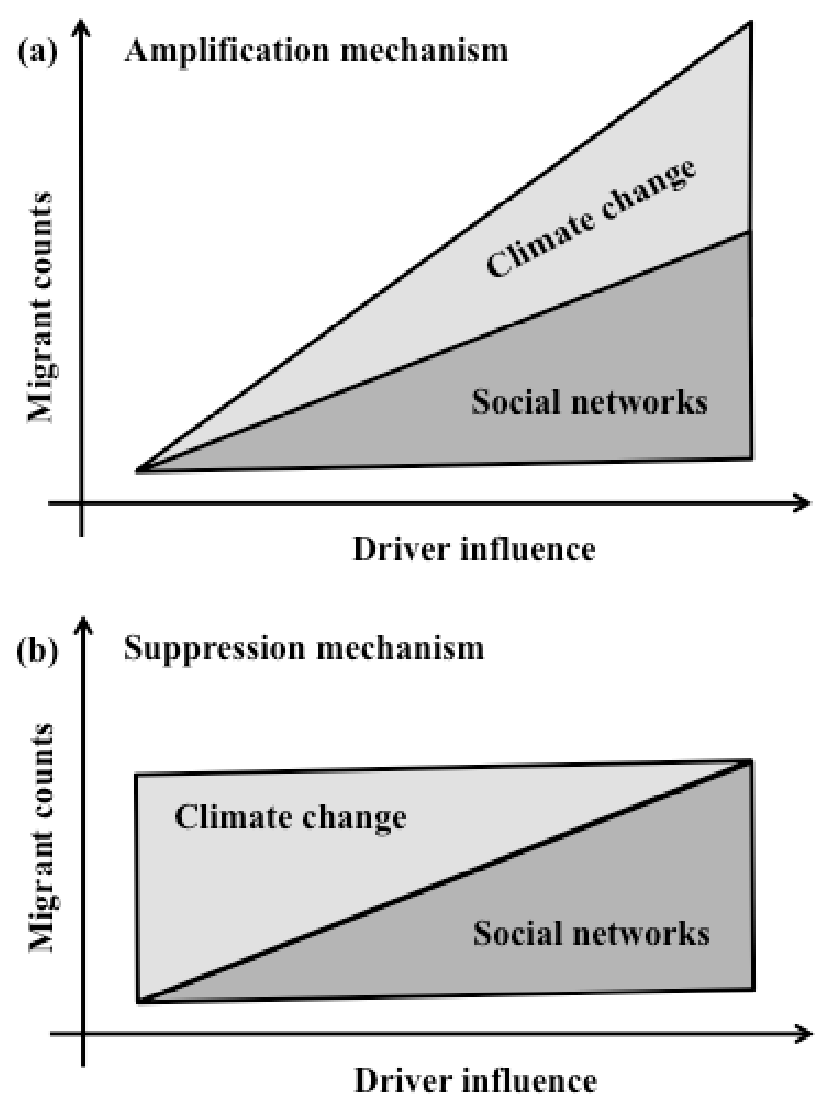
Figure 4: Interaction between warm spell duration (a) and percentage warm nights (b) and community migrant networks in predicting the odds of a first international move from rural Mexico
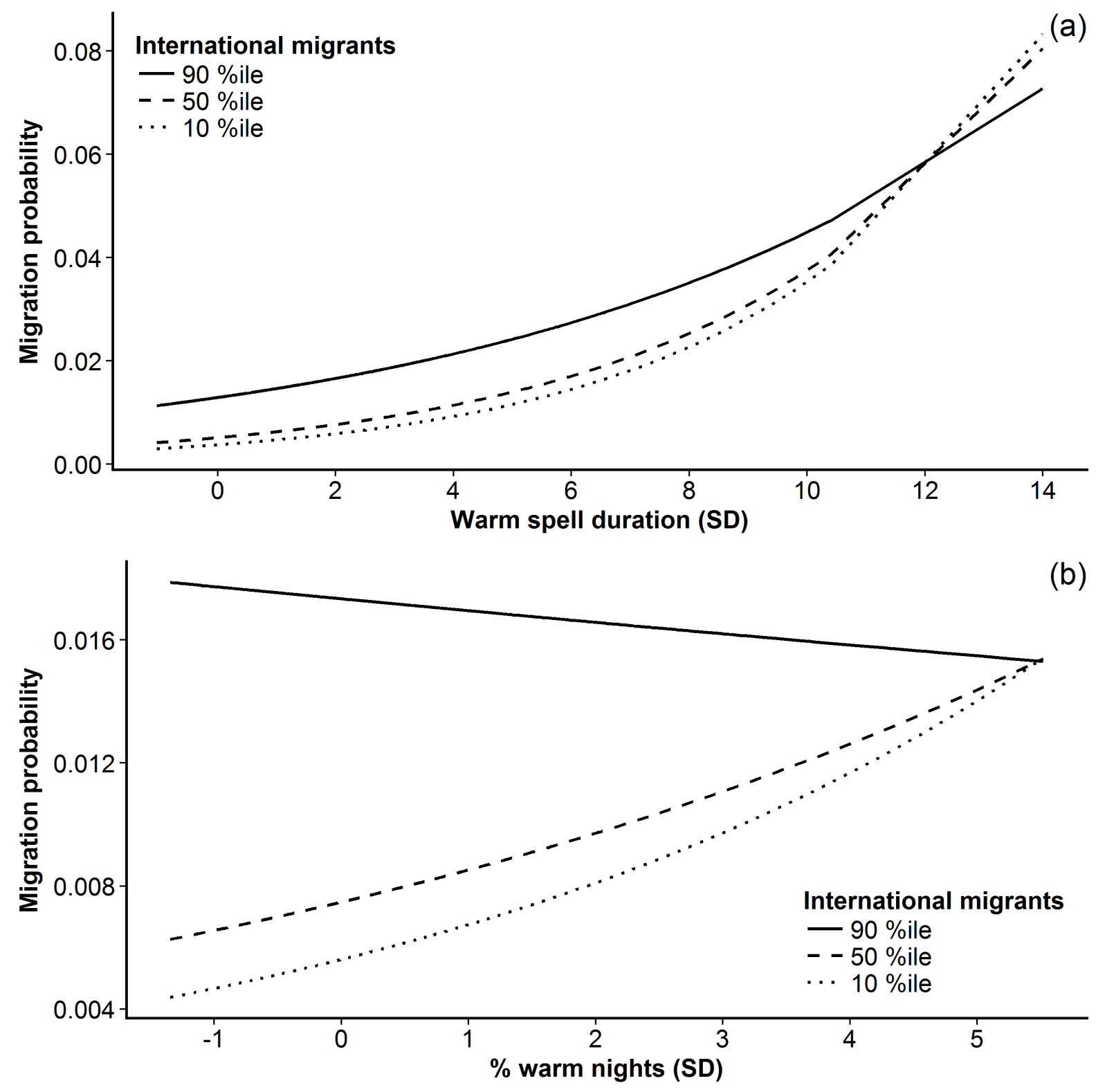